\title{
Protein from preprocessed waste activated sludge as a nutritional supplement in chicken feed
}

\author{
Evans M. N. Chirwa and Moses T. Lebitso
}

\begin{abstract}
Five groups of broiler chickens were raised on feed containing varying substitutions of single cell protein from preprocessed Waste Activated Sludge (pWAS) in varying compositions of 0:100, 25:75, 50:50, 75:25, and 100:0 pWAS: Fishmeal by mass. 40 chickens per batch were evaluated for growth rate, mortality rate, and feed conversion efficiency $\left(\eta_{\epsilon}\right)$. The initial mass gain rate, mortality rate, initial and operational cost analyses showed that protein from pWAS could successfully replace the commercial feed supplements with a significant cost saving without adversely affecting the health of the birds. The chickens raised on preprocessed WAS weighed 19\% more than those raised on fishmeal protein supplement over a 45 day test period. Growing chicken on pWAS translated into a $46 \%$ cost saving due to the fast growth rate and minimal death losses before maturity.

Key words | biosolid resource recovery, feed conversion efficiency, feed formulation, protein supplement, waste activated sludge
\end{abstract}

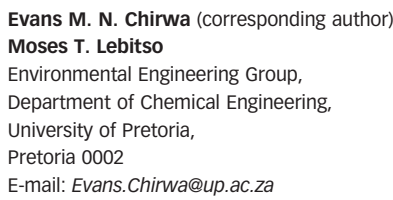

E-mail: Evans.Chirwa@up.ac.za

\section{$\overline{\text { INTRODUCTION }}$}

Underdeveloped regions around the world are affected by high malnutrition rates among children under the age of five (Konczacki 1972; Clover 2003). Declining economic conditions in these regions adversely affect the affordability and availability of high quality food stuffs. Specifically, prices of commercially grown meat products have been on the increase in the past four decades mainly due to rising cost in agricultural products including feed stocks (Shipton \& Hecht 2005; Briedenhann 2009). The price of meat is affected by the cost of the feed meal especially the protein component most of which is imported.

In most countries around the world, large amounts of activated sludge are disposed in a variety of final disposal facilities. Sludge is conventionally disposed of through combustion, landfilling, ocean dumping at coastal cities, soil application as fertilizers and soil conditioners (Hwang et al. 2008). These methods, in some cases, require large capital investments more than any other part of wastewater treatment process (Vriens et al. I989; Hwang et al. 2008). Additionally, soil application poses an environmental risk as it may result in contamination of groundwater and surface water resources due to leaching of heavy metals and phosphorous (Kasselman 2004; Ezejiofor et al. 20I3).
The amount of protein wasted through disposed sludge far exceeds the import requirements of fishmeal by values ranging from two to three times the regional shortfall in protein supplements. A large component of the wasted sludge comprises of the single cell protein from mesophilic bacteria. In other studies, it has been demonstrated that waste activated sludge (WAS) from sewage treatment plants contains a wide range of important nutrients, thus, it offers an enormous potential as a possible animal feed supplement (Freeman et al. 2008; Kenge 2008). The amounts of mineral elements, vitamins, nucleic acids, and amino acid proteins, reported by Vriens et al. (I989) are comparable to amounts present in whole egg, symba yeast sludge, soybean and fishmeal (Table 1).

Although the WAS shows such high potential, other studies have also shown that the level of toxic heavy metal content in sludge is usually very high (typically two orders of magnitude higher than the levels in conventional protein sources such as fishmeal and soya meal) (Nelson et al. I98I; Malamis et al. 20I2). Additionally, recalcitrant organic pollutants originating from industrial processes can accumulate in the organisms that form the largest component of WAS (Barnhoorn et al. 2004). Therefore, it is recommended that the WAS be intensively pre-treated to remove heavy metals and other priority organic pollutants. 


\begin{tabular}{|c|c|c|c|c|c|c|}
\hline Amino Acid & WAS & Soyabean meal & White fish meal & FAO ref. protein & Wheat & Whole egg \\
\hline Alanine & 7.30 & - & - & - & - & - \\
\hline Glycine & 4.90 & - & - & - & - & - \\
\hline Valine & 4.10 & 5.2 & 4.7 & 4.2 & 4.4 & 7.3 \\
\hline Threonine & 4.20 & 4.4 & 3.8 & 2.8 & 2.9 & 5.1 \\
\hline Serine & 3.40 & - & - & - & - & - \\
\hline Leucine & 5.60 & 7.6 & 6.5 & 4.8 & 6.7 & 8.9 \\
\hline Isoleucine & 2.70 & 5.8 & 3.9 & 4.2 & 3.3 & 6.7 \\
\hline Proline & 3.10 & - & - & - & - & - \\
\hline Methionine & 1.45 & 1.3 & 2.9 & 2.2 & 1.5 & 3.2 \\
\hline Aspartic acid & 8.30 & - & - & - & - & - \\
\hline Phenylalanine & 3.10 & 5.3 & 3.5 & 2.8 & 4.5 & 5.8 \\
\hline Glutamic acid & 8.10 & - & - & - & - & - \\
\hline Lysine & 3.30 & 6.6 & 7.6 & 4.2 & 2.8 & 6.5 \\
\hline Tyrosine & 2.40 & 4.1 & 3 & 2.8 & - & - \\
\hline Arginine & 2.90 & 7.3 & 6.8 & - & - & - \\
\hline Histidine & 0.60 & 2.7 & 2 & - & - & - \\
\hline Cystine & 2.10 & 1.2 & 0.7 & 2 & 2.5 & 2.4 \\
\hline Tryptophan & 0.80 & 1.3 & 0.9 & 1.4 & 1.1 & 1.6 \\
\hline
\end{tabular}

In this study, a simple process involving prewashing of WAS with dilute acid was employed to lower the levels of toxic heavy metals to produce a preprocessed waste activated sludge (pWAS). The pWAS was supplied to juvenile chicken in ratios ranging from 0 to $100 \%$ replacement of fishmeal and the growth rate and the general health of the chicken was monitored over a period of 45 days.

\section{MATERIALS AND METHODS}

\section{Crude protein determination}

$1 \mathrm{~g}$ dry weight samples collected from Bavianspoort, Zeekoeigat and Rooiwal sewage works were ignited in a quartz combustion tube of an induction furnace operated at $900{ }^{\circ} \mathrm{C}$ with a helium and oxygen carrier phase. An aliquot of the combustion gases was passed through a copper catalyst mounted on the quartz combustion tube to remove oxygen and convert nitrous oxides to $\mathrm{N}_{2}$ (gas). The sample was scrubbed of moisture and carbon dioxide, and nitrogen content was determined by thermal conductivity. Total crude protein was calculated from the nitrogen content of the feed material. Pure protein from sludge was analysed within four hours after collection of the sludge from the wastewater treatment plants. Proteins were thermally mobilised at $120^{\circ} \mathrm{C}$ (in an autoclave) or at $155^{\circ} \mathrm{C}$ in a mineral oil heated on a hot plate. Pure protein content was assayed using the Coomassie protein reagent (Sedmak \& Grossberg 1977). The method has a detection limit of $0.1 \%$ protein (dry basis) and is generally reproducible within 5\% error margin (AOAC 2006).

\section{Amino acid analysis}

The amino acid distribution fingerprint (AADF) from the activated sludge sources was compared against the AADF of the proteins in the commercial feed supplement (fishmeal) using the Pico-tag method (Bidlingmeyer et al. 1984). This involved hydrolysis of the protein to yield free amino acids through the pre-column derivatisation of the sample followed by analysis by Reverse Phase High Performance Liquid Chromatography (RP-HPLC). The HPLC was operated following the EPA Method 604 using a Symmetry C18 $150 \times 3.9,5 \mu \mathrm{m}$ column. A binary gradient mobile phase consisting of $1 \%$ acetic acid in water and 1\% acetic acid in acetonitrile was used at a flow rate of $1.2 \mathrm{~mL} / \mathrm{min}$. The analysis was conducted in the Waters HPLC 2695 using the Waters Photo Diode Array (Waters 2998 PDA) (Waters Corp., Milford, MA). 


\section{Nucleic acid content analysis}

Samples were analyzed on 1.5\% (w/v) agarose (promega, Wisconsin, USA)/TAE (0.04 M tris-acetate, $1 \mathrm{mM}$ EDTA) gels by electrophoresis in $1 \times \mathrm{TAE}$ at $78 \mathrm{~V}(5.2 \mathrm{~V} / \mathrm{cm})$ in a minicell EC $370 \mathrm{M}$ electrophoretic system (E-C Apparatus Corporation, USA), loaded with dye, i.e., 30\% (v/v) glycerol, $0.025 \%(\mathrm{w} / \mathrm{v})$ bromophenol blue. The gel was subsequently stained in a $10 \mu \mathrm{g} / \mathrm{ml} \mathrm{EtBr}$ solution and the bands were visualised on a spectroline TC-312A UV transilluminator at $312 \mathrm{~nm}$. Images were captured with a charge-coupled device camera linked to a computer system.

\section{Heavy metal analysis}

The heavy metal content $(\mathrm{Zn} ; \mathrm{Cu} ; \mathrm{Cd} ; \mathrm{Mn} ; \mathrm{Pb})$ of the sludge was determined using Inductive Coupled Plasma - Mass Spectrometer (ICP-MS). The samples (2 gram parts) were digested for $30 \mathrm{~min}$ with concentrated nitric and perchloric acid, the samples were then cooled to room temperature and then diluted to $200 \mathrm{ml}$ with distilled water. Metals were then analysed in the leachate following the U.S.EPA Method 200.7 (I979) using the ICP-OES (Perkin-Elmer, Inc., Waltham, MA).

\section{Pretreatment to remove metals}

In this project, heavy metals were extracted using a dilute acid $(1 \mathrm{~N} \mathrm{HCl})$ following the method developed by Yoshikazi \& Tomida (2000). The effectiveness of the process was tested on a small scale by shaking the sludge sample on the horizontal shaker with the appropriate acid $(1 \mathrm{~N}$ $\mathrm{HCl}, 0.1 \mathrm{M}$ citric or $0.1 \mathrm{M}$ oxalic acid) for a specified time, followed by filtering the samples. The metal content in the supernatant and the residues were determined in separately overnight dried samples $\left(\right.$ at $110^{\circ} \mathrm{C}$ ) and ignited samples (at $550{ }^{\circ} \mathrm{C}$ ). Samples were then digested in aqua regia, and then diluted accordingly. The heavy metal content in the samples was determined by FAAS (Varian 1989). From the above test, we chose the optimum time yielding the maximum metal removal with minimum protein loss and this was selected as the pretreatment time for the WAS.

\section{Pilot study on poultry}

\section{Brooding}

House preparation was completed prior to chick arrival and that enabled placement of chicks into the brooding area immediately upon arrival. The feeding area was overlaid with paper. The noise produced during movement across the feeding area encouraged the development of efficient perching habits. Coefficient of Variation for each sector was reported as an indicator of feeding consistency and chick condition in each group.

\section{Feed formulations}

When formulating feed ratios, the equivalent sludge volume of one portion of fishmeal was determined by the protein content in the pre-processed pWAS taking into consideration the reduction in the amino acid content. In this study, up to two thirds of the critical amino acids were lost during pretreatment. Therefore, the treated sludge volume intended to replace one part of fishmeal was multiplied by a factor of 1.5 , which slightly decreased the feed conversion efficiency $\left(\eta_{\epsilon}\right)$ in the chickens grown on pWAS.

\section{Stocking density}

The experimental units were further divided into groups of 10 for easy handling and observation. Each experimental unit started with 3 subgroups of approximately 10 chicks per subgroup. Overcrowding was avoided out of biological necessity. Initial stocking densities were made up of 10 chicks per $1 \mathrm{~m}^{2}$ until approximately 4 days of age. After this, space was progressively increased and access to the whole house was given from 14 days. The final area designated for every 10 chicks was $20 \mathrm{~m}^{2}$.

\section{RESULTS AND DISCUSSION}

\section{Metal content in Raw sludge}

Metals found in sewage sludge included mercury, zinc, copper, manganese, lead, cadmium, and chromium which have undesirable health effects on living organisms. Metal concentrations above the allowable limits were detected as shown in Table 2. Fishmeal had much lower concentrations of metals than WAS and pWAS. An effort to decrease content of metals from the sludge involved washing raw sludge with a dilute $\mathrm{HCl}$. A mass reduction was evident in acid washed sludge indicating possibility of reduction of the nutritional value due to the leaching process. The amount of metals after leaching with acid was still too high. Notably, chromium as $\mathrm{Cr}$ (III) approached the regulation limit of $1,000 \mathrm{~g} / \mathrm{m}^{3}$ before mixing with the 
Table 2 | Quantities of heavy metals found in samples

\begin{tabular}{|c|c|c|c|c|}
\hline $\begin{array}{l}\text { Element (as } \\
\text { Oxide) }\end{array}$ & $\begin{array}{l}\text { Average } \\
\text { Standard error }\end{array}$ & $\begin{array}{l}\text { Dry Sludge } \\
(\mathrm{g} / 100 \mathrm{~g})\end{array}$ & $\begin{array}{l}\text { Fish meal } \\
\text { (g/100 g) }\end{array}$ & $\begin{array}{l}\text { Leached } \\
\text { Sludge } \\
\text { (g/100 } \mathrm{g})\end{array}$ \\
\hline $\mathrm{TiO}_{2}$ & 0.03 & 0.85 & 0.06 & 1.12 \\
\hline $\mathrm{Al}_{2} \mathrm{O}_{3}$ & 0.10 & 3.79 & 3.98 & 4.02 \\
\hline $\mathrm{Fe}_{2} \mathrm{O}_{3}$ & 0.22 & 9.77 & 0.69 & 8.97 \\
\hline $\mathrm{MnO}$ & 0.00 & 0.16 & 0.02 & 0.08 \\
\hline $\mathrm{MgO}$ & 0.10 & 1.80 & 0.36 & 0.90 \\
\hline $\mathrm{CaO}$ & 0.29 & 4.88 & 22.60 & 2.34 \\
\hline $\mathrm{CdO}$ & 0.01 & 0.02 & 0.00 & $n d^{b}$ \\
\hline $\mathrm{Cr}_{2} \mathrm{O}_{3}$ & 0.00 & 0.13 & 0.00 & 0.14 \\
\hline $\mathrm{NiO}$ & 0.00 & 0.04 & 0.00 & 0.02 \\
\hline $\mathrm{ZrO}_{2}$ & 0.00 & 0.03 & 0.00 & 0.04 \\
\hline $\mathrm{BaO}$ & 0.00 & 0.11 & 0.00 & 0.12 \\
\hline $\mathrm{CuO}$ & 0.01 & 0.16 & 0.01 & 0.19 \\
\hline $\mathrm{ZnO}$ & 0.05 & 3.14 & 0.07 & 1.88 \\
\hline $\mathrm{PbO}$ & 0.00 & 0.03 & 0.01 & 0.03 \\
\hline
\end{tabular}

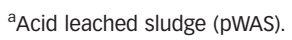

${ }^{\mathrm{b}}$ Not detectable.

carbohydrate meal. The metals $\mathrm{Ca}^{2+}$ and $\mathrm{Fe}^{3+}$, though detected at higher levels than the rest of the metals, are within the acceptable limits commonly found in food supplements. Based on these results we recommend that other methods be investigated to further reduce the metal content before application of pWAS as a substitute of conventional protein supplements in feed meal.

\section{Amino acid distribution}

Sludge in general was found to have high amounts of amino acids when compared to the amounts required in starter, grower and finisher feed formulations in chicken (Figure 1). Based on the analytical comparative results in shown in Figure 2, it was confirmed that all essential amino acids were present in the untreated WAS. The chosen pretreatment process, i.e., acid wash followed by autoclaving at $120^{\circ} \mathrm{C}$, preserved all critical amino acid components in the final product. Only less than $10 \%$ of amino acids were lost mainly from phenylalamine (with 40\% measured loss in phenylalamine during acid washing) (Figure 2(a)). The content of amino acids was directly proportional to the distribution in the commercial protein supplement (fishmeal) with the highest disparity observed in phenylalamine and serine at 65 and $70 \%$ difference, respectively (Figure 2(b)).

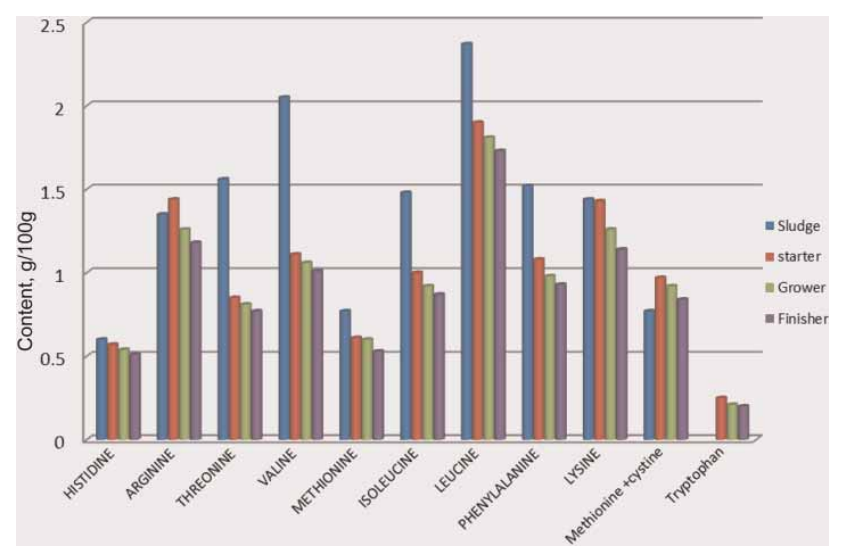

Figure 1 | Amino acids distribution (g/100 g) of WAS compared to the chicken feed requirements in starters, growers and finishers.
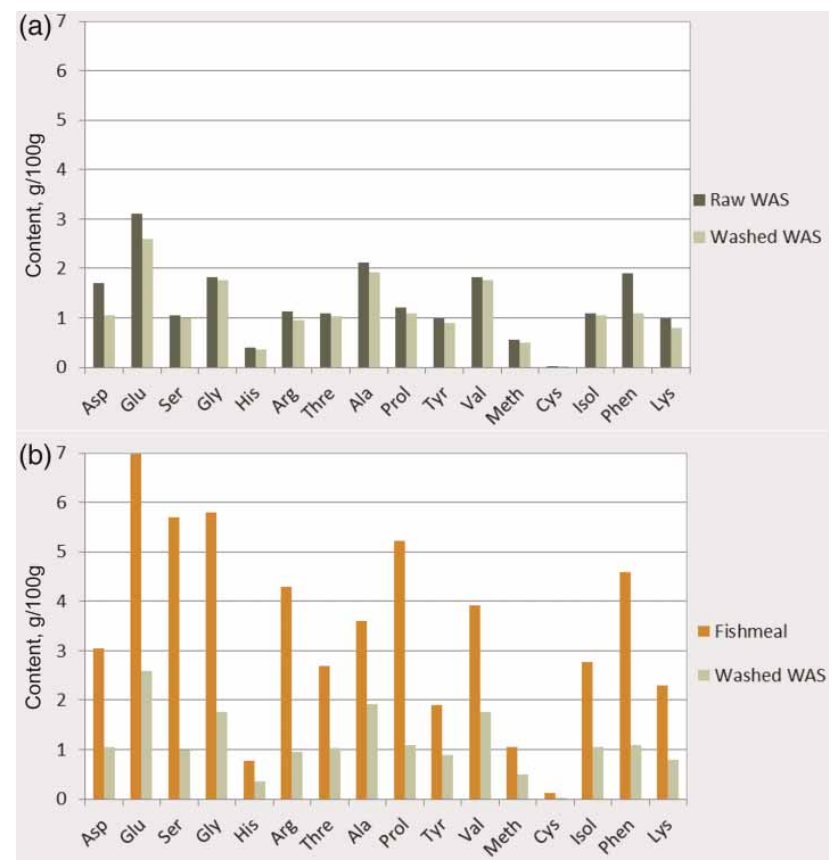

Figure 2 | (a) Comparative analysis of amino acid content for sludge before and after pretreatment, showing minimal losses in amino acids after treatment and autoclaving, and (b) Comparative analysis of amino acid content between commercial feed (fishmeal) and pWAS.

Further analysis of the results indicates that the ratio of lysine to methionine, an important nutritional factor (Vriens et al. 1989), is nearly equal to 2 , which compares well with that of fishmeal (which is nearly 2.1).

The processed WAS was generally deficient in the amino acid tryptophan which imparts immunological properties in chicken (Emadi et al. 2010). However, the high levels of methionine and cysteine compensates for the tryptophan deficiency. This immunity compensation effect 
by other amino acid components was earlier demonstrated in study on the Bursal disease by Maroufyan et al. (20I0). In the study by Maroufyan et al., chicken grown on feed rich in methionine and cysteine acquired immunity against Bursal disease even when the feed was deficient in tryptophan.

The results in Figure 2(a) show that the critical amino acids, cysteine and histidine, were lost in significant proportions during acid washing process. The feed formulation took into these losses into consideration by balancing the proportion to ensure the presence of the highly reduced amino acids.

\section{Nucleic acid content}

Total nucleic acid determination using gel electrophoresis showed positive results for existence of nucleic acids in extracted proteins from the pWAS. The higher DNA content from the pWAS which is predominantly prokaryotic is expected (Yang et al. 1979). The high levels of nucleic acids in the single cell protein (SCP) renders the supplement unsuitable for polygastric ruminants since the same proteins will be generated by microorganisms in the rumen of polygastric animals (Offermanns \& Tanner 1982). However, moderate amounts of nucleic acids especially from ribosomal RNA complexes could be beneficial to the chickens as they could serve as an additional source of dietary nitrogen in animal feed supplements. Additionally, nucleic acids from RNA have been known to serve as building blocks for protein building and contribute in boosting the immune system response to skin damage thereby increasing the rate of wound healing (Pal'tsyn \& Kolokol'chikova 1979).

\section{Broiler pilot studies}

\section{Feed formulation with $0,25,50,75$ and $100 \%$ pWAS as percent substitution of fishmeal}

The chicken responded different to different protein supplement substitution ratios (pWAS:fishmeal). Table 3 shows the mass gain rates at different times during the experiment. Apart from the slight variation in the mass growth rate in the $50 \% \mathrm{pWAS} / 50 \%$ and $75 \% \mathrm{pWAS} / 25 \%$ fishmeal batchs (Table 3, columns $2 \& 3$ ), the growth rate in the different groups is within the same degree of error to the control group.

The results in Table 3 show that more feed was taken up by birds feed with pWAS substitution to convert a unit mass of meat at any specific age. But since the cost of the
Table 3 Weight gain analysis for broilers feed with different protein feed supplement substitutions using pWAS in the ratios ranging from 0 to $100 \%$ pWAS

\begin{tabular}{|c|c|c|c|c|}
\hline $\begin{array}{l}\text { Feed } \\
\text { formulation } \\
\text { pWAS: } \\
\text { Fishmeal (\%) }\end{array}$ & $\begin{array}{l}\text { Beginning rate, } \\
0-10 \text { days ( } \mathrm{g} \\
\text { chick/d) }\end{array}$ & $\begin{array}{l}\text { Ending rate, } \\
25-35 \text { days ( } g \\
\text { chick/d) }\end{array}$ & $\begin{array}{l}\text { Initial } \\
\text { FCR }^{\text {a }}(\mathrm{g} \\
\text { chick/g } \\
\text { feed.d) }\end{array}$ & $\begin{array}{l}\text { Final } \\
\text { FCR }^{\mathrm{a}}(\mathrm{g} \\
\text { chick/g } \\
\text { feed } \cdot d)\end{array}$ \\
\hline $0: 100$ & $18.32 \pm 0.40$ & $91.18 \pm 0.99$ & 0.008 & 0.052 \\
\hline $25: 75$ & $18.64 \pm 0.55$ & $91.88 \pm 0.89$ & 0.009 & 0.057 \\
\hline $50: 50$ & $28.24 \pm 0.56$ & $75.82 \pm 1.06$ & 0.011 & 0.051 \\
\hline $75: 25$ & $28.85 \pm 0.39$ & $90.62 \pm 0.77$ & 0.013 & 0.062 \\
\hline 100:0 & $27.18 \pm 0.32$ & $89.86 \pm 0.44$ & 0.013 & 0.064 \\
\hline
\end{tabular}

${ }^{\mathrm{a}} \mathrm{FCR}=$ short-term feed conversion rate calculated as $\mathrm{g}$ chicken per gram feed per day.

processing the pWAS is much lower than the cost of production and importation of fishmeal, the slight weight conversion efficiency advantage obtained from feeding the birds with fishmeal does not offset the cost savings obtained from supplementing the feed with pWAS. The financial benefit of using pWAS is demonstrated later in this article.

These results show that the chicken feed with $100 \%$ pWAS responded best to the feeding regime than the chicken with fractional feeds of fishmeal. This further suggests that the feeding of the chicken with pWAS did not negatively affect the health of the chicken. The later result was confirmed by low mortality rates in the chicken provided with pWAS only.

\section{Feed conversion efficiency and mortality effects}

Feed intake and its efficient utilization are of significant concern in poultry, as feed cost is one of the highest components of total production cost (Rosário et al. 2007); it is a measure of an animal's efficiency in converting feed mass into increased body mass. Feed alone may contribute up to $70 \%$ of the total cost of production in broiler chickens. Data listed in Table 4 show that, when chicks are fed with conventional feed, they consume $50 \%$ less feed to produce the same weight as chicks fed $100 \%$ pWAS. The contributing factor to this phenomenon was probably the larger component of supplementary WAS required to replace the unit mass of fishmeal - one part fishmeal was substituted with three parts WAS.

\section{Cost benefit analysis}

The feeding experiment cost was US\$ 64.82 in a block of 50 chicks (9 chicks died in the group of 50). The cost was shared as follows: US\$ 13.52 per ten chicken fed with 
Table 4 The effect of pWAS on overall performance of broiler chicks (0 to 6 weeks)

\begin{tabular}{|c|c|c|c|c|c|}
\hline pWAS level (\%) & $\mathbf{0}$ & 25 & 50 & 75 & 100 \\
\hline \multicolumn{6}{|l|}{ Mortality \% } \\
\hline 0 to 10 days & 20.00 & 10.00 & 10.00 & 20.00 & 10.00 \\
\hline 11 to 24 days & 0.00 & 11.11 & 0.00 & 0.00 & 11.11 \\
\hline 25 to 35 days & 0.00 & 0.00 & 0.00 & 0.00 & 0.00 \\
\hline Total mortality (in 6 weeks) & 20.00 & 21.11 & 10.00 & 20.00 & 21.11 \\
\hline \multicolumn{6}{|c|}{ Feed Conversion Efficiency Analysis } \\
\hline Total feed intake (g/bird) & 4,675 & 4,925 & 4,848 & 5,678 & 5,928 \\
\hline Total weight gained (g/bird) & $2,015.25$ & $1,930.38$ & $2,250.67$ & $2,249.25$ & $2,676.38$ \\
\hline Feed conversion efficiency, $\eta_{\epsilon}{ }^{\mathrm{a}}$ & 0.43 & 0.39 & 0.46 & 0.40 & 0.45 \\
\hline
\end{tabular}

${ }^{\mathrm{a}}$ Feed conversion efficiency $\left(\eta_{\epsilon}\right)=\mathrm{g}$ meat $/ \mathrm{g}$ feed.

conventional feed; US\$ 13.13 per ten chicken fed with 75\% fishmeal: $25 \%$ sludge; US\$ 13.02 for per chicken fed with 50\% fishmeal: 50\% sludge; US\$ 12.83 per ten chicken fed with 25\% fishmeal: $75 \%$ sludge; and US\$ 12.32 per ten chicken fed with $0 \%$ fishmeal: $100 \%$ sludge. This translated into cost for raising one chicken as follows - US\$ $0.48 / \mathrm{kg}$ raised on $100 \%$ fishmeal, US\$ $0.50 / \mathrm{kg}$ raised on $75 \%$ fishmeal, US\$ $0.38 / \mathrm{kg}$ raised on $50 \%$ fishmeal, US\$ $0.43 / \mathrm{kg}$ raised on $25 \%$ fishmeal, and US\$ $0.39 / \mathrm{kg}$ raised on $0 \%$ fishmeal and $100 \%$ sludge. The data translates into a total mass gain of 19\% in chicken feed with 100\% sludge in comparison with the chicken feed $100 \%$ fishmeal with a cost saving of $46 \%$.

\section{CONCLUSION}

The study shows compatibility between the amino acids distribution in fishmeal and preprocessed WAS (pWAS). This suggests that protein from WAS could be recovered indirectly through animal feedstock. However, the level of metals detected in the WAS was beyond the allowable limits for feed products even after leaching with acid. This calls for an improvement in the pretreatment method to remove pollutants. In the current study, no adverse effects were observed in the birds fed with the pWAS. The adjustment of pWAS mass for amino acid losses may have increased nutrient loading thereby slightly affecting the growth rates. The study serves as the basis for further studies on the optimization of pretreatment to remove pollutants and heavy metals.

\section{ACKNOWLEDGEMENTS}

We thank the University of Pretoria for the support through the Research Development Programme (UP-RDP) fund awarded to E.M.N. Chirwa. The master's student Moses Lebitso was funded by Sedibeng Water. Analysis was conducted in the Department of Biochemistry at the University of Pretoria.

\section{REFERENCES}

AOAC Official Method 990.032006 In Official Methods of Analysis of AOAC International, 16th edn, Volume I, Chapter 4, pp. 18-19.

Barnhoorn, I. E. J., Bornman, M. S., Pieterse, G. M. \& van Vuren, J. H. J. 2004 Histological evidence of intersex in feral sharptooth catfish (Clarias gariepinus) from an estrogenpolluted water source in Gauteng, South Africa. Environmental Toxicology 19 (6), 603-608.

Bidlingmeyer, B. A., Cohen, S. A. \& Tarvin, T. L. 1984 Rapid analysis of amino acids using pre-column derivatization. Journal of Chromatography 336 (1), 93-104.

Briedenhann, E. 2009 Chairman's Report 2008/2009 to the Animal Feed Manufacturers Association. AFMA Annual General Meeting, Euphoria Golf Estate \& Hydro, 4 September 2009, Mookgopong, Naboomspruit), South Africa.

Clover, J. 2003 Food security in Sub-Saharan Africa. African Security Review 12 (1). The United Nations Food and Agricultural Organisation (FAO). Available online at http:// www.issafrica.org/pubs/ASR/12No1/Clover.pdf. Last accessed on 6 April 2013 at 14:00.

Emadi, M., Jahanshiri, F., Kaveh, K., Hair-Bejo, M., Ideris, A. \& Alimon, R. 2oro Tryptophan stimulates immune response in 
broiler chickens challenged with infectious Bursal Disease Vaccine. Journal of Animal and Veterinary Advances 9 (3), 610-616.

Ezejiofor, T. I. N., Ezejiofor, A. N., Udebuanil, A. C., Ezeji, E. U., Ayalogbu, E. A., Azuwuike, C. O., Adjero, L. A., Ihejirika, C. E., Ujowundu, C. O., Nwaogu, L. A. \& Ngwogu, K. O. 2013 Environmental metals pollutants load of a densely populated and heavily industrialized commercial city of Aba, Nigeria. Journal of Toxicology and Environmental Health Sciences 5 (1), 1-11.

Freeman, S. R., Poore, M. H., Huntington, G. B. \& Middleton, T. F. 2008 Evaluation of secondary protein nutrients as a substitute for soybean meal in diets for beef steers and meat goats. Journal of Animal Science 86 (1), 146-158.

Hwang, J., Zhang, L., Seo, S., Lee, Y. \& Jahng, D. 2008 Protein recovery from excess sludge for its use as animal feed. Bioresource Technolology 99 (18), 8949-8954.

Kasselman, G. 2004 An Evaluation of Predictive Environmental Test Procedures for Sewage Sludge. M.Sc. Dissertation, University of Pretoria, Pretoria, South Africa.

Kenge, A. A. 2008 Enhancing Nutrient Solubilization from Organic Waste Using the Microwave Technology. Master's Thesis, The University of British Columbia, Vancouver, Canada.

Konczacki, Z. A. 1972 Infant malnutrition in Sub-Saharan Africa: a problem in socio-economic development. Canadian Journal of African Studies 6 (3), 433-449.

Malamis, S., Katsou, E., Daskalakis, N. \& Haralambous, K. J. 2012 Investigation of the inhibitory effects of heavy metals on heterotrophic biomass activity and their mitigation through the use of natural minerals. Journal of Environmental Science and Health. Part A, Toxic/Hazardous Substances \& Environmental Engineering 47 (13), 1992-1999.

Maroufyan, E., Kasim, A., Hashemi, S. R., Loh, T. C., Bejo, M. H. \& Davoodi, H. 2oro The effect of methionine and threonine supplementations on immune responses of broiler chickens challenged with infectious Bursal Disease. American Journal of Applied Sciences 7 (1), 44-50, 2010.

Nelson, P. O., Chung, A. K. \& Hudson, M. C. I98I Factors affecting the fate of heavy metals in the activated sludge process.
Journal (Water Pollution Control Federation) 53 (8), 1323-1333.

Offermanns, H. \& Tanner, H. I982 Rumen-Protected Amino Acids. In: Chemistry and World Food Supplies: The New Frontiers, Chemrawn II (L.W. Shemilt, ed.). Pergamon Press, NY, pp. 373-381.

Pal'tsyn, A. A. \& Kolokol'chikova, E. T. 1979 Sequence of RNA and protein synthesis in wound fibroblasts. Arkhiv Anatomii, Gistologii i Émbriologii 77 (9), 97-103.

Rosário, M. F., Silva, M. A. N., Coelho, A. A. D. \& Savino, V. J. M. 2007 Estimating and predicting feed conversion in broiler chickens by modeling covariance structure. International Journal of Poultry Science 6 (7), 508-514.

Sedmak, J. J. \& Grossberg, S. E. I977 A rapid sensitive, and versitile assay for protein using Coomassie briliant blue G250. Analytical Biochemistry 79 (1-2), 544-552.

Shipton, T. A. \& Hecht, T. 2005 A review of the animal and aquafeed industries in South Africa. In: A Synthesis of the Formulated Animal and Aquafeed Industry in Sub-Saharan Africa. (J. Moehl \& M. Halwart, eds) Food and Agriculture Organization of the United Nations, Rome. Available online: http://www.fao.org/docrep/008/a0042e/a0042e04.htm. Last accessed on 6 April 2013 at 14:00.

U.S.EPA Method 200.7 I979 Determination of Metals and Trace Elements in Water and Wastes by Inductively Coupled Plasma-Atomic Emission Spectrometry - Revision 4.4, EMMC Version. Environmental Monitoring Systems Laboratory, U. S. Environmental Protection Agency, Cincinnati, Ohio.

Varian 1989 Analytical Methods For Flame Spectroscopy. Publication No. 85-100009-00, Varian Techtron Pty. Ltd., Springvale, Australia.

Vriens, L., Nihoul, R. \& Verachtert, H. I989 Activated sludge as animal feed: a review. Biological Wastes 27 (3), 161-207.

Yang, H.-.H., Thayer, D. W. \& Yang, S. P. 1979 Reduction of endogenous nucleic acid in a Single-Cell Protein. Applied and Environmental Microbiology 38 (1), 143-147.

Yoshikazi, S. \& Tomida, T. 2000 Principle and process of heavy metal removal from sewage sludge. Environmental Science and Technology 34 (8), 1572-1575. 